\title{
Waste cooking oil processing for fatty acid methyl ester and mono glycerides production with magnetite catalyst
}

\author{
1,2,3* Widayat, ${ }^{1}$ Hadiyanto, ${ }^{1,2}$ Putra, D.A., ${ }^{1,2}$ Nursafitri, I., ${ }^{1}$ Satriadi, H. and ${ }^{1,2}$ Prameswari, J. \\ ${ }^{1}$ Chemical Engineering Department, Faculty of Engineering, Diponegoro University, Indonesia \\ ${ }^{2}$ Advanced Material Laboratory Central of Research and Service Unit Diponegoro University, Indonesia \\ ${ }^{3}$ Halal Research Center Central of Research and Service Unit Diponegoro University, Indonesia
}

\begin{abstract}
Article history:
Received: 20 August 2019

Received in revised form: 18

December 2019

Accepted: 31 January 2020

Available Online: 10

February 2020
\end{abstract}

\section{Keywords:}

Free fatty acid methyl ester,

Magnetite catalyst,

Monoglycerides,

Waste cooking oil

DOI:

https://doi.org/10.26656/fr.2017.4(S1).S29

\begin{abstract}
The objective of this research was to produce biodiesel using waste cooking oil and various magnetite catalysts with the esterification-transesterification process. Magnetite catalysts tested were $\alpha-\mathrm{Fe}_{2} \mathrm{O}_{3}, \alpha-\mathrm{Fe}_{2} \mathrm{O}_{3} / \mathrm{Al}_{2} \mathrm{O}_{3}, \alpha-\mathrm{Fe}_{2} \mathrm{O}_{3} / Z \mathrm{ZM}-5$ catalysts. Catalysts were prepared through chemical precipitation and calcination. The esterificationtransesterification process was carried out with the conditions WCO: methanol molar ratio of $15: 1$, catalyst ( $1 \% \mathrm{wt}$ of oil), heated at $65^{\circ} \mathrm{C}$ for $3 \mathrm{hrs}$. The results showed biodiesel production using $\alpha-\mathrm{Fe}_{2} \mathrm{O}_{3}-\mathrm{ZSM}-5$ catalyst obtained higher \%FAME (83.28\%), yield $(91.915 \%)$ and monoglyceride content $(16.72 \%)$ compared to others due to larger pore volume. Biodiesel produced passed the requirement of Indonesian National Standard (SNI) based on density, acid number and viscosity.
\end{abstract}

\section{Introduction}

Palm oil is one of the most important agricultural products in Indonesia. The national Crude Palm Oil (CPO) production has increased by $8 \%$ from $32.18 \mathrm{MT}$ in 2017 to 34.71 MT in 2018. It is predicted that by 2019 it will grow by $5 \%$ (Deha, 2019). CPO was used as raw material in cooking oil production. Cooking oil is widely used not only in household capacity but also in industries. Consequently, used cooking oil is abundant as waste. Waste cooking oil (WCO) refers to vegetable oil that has been used in food production and no longer viable for its intended use. WCO is a potentially problematic waste stream which requires proper management. The problem arises lately as many restaurants and hotels sold WCO to other dealers, which then recycle it. The recycled oil supposedly should not be used for cooking as it is unfit for consumption, causing health hazards when it is consumed or used in processing products (Tsai, 2019).

WCO can be converted to cooking oil through adsorption. The adsorbent used could be bentonite and zeolite (Widayat et al., 2006). However, WCO can also be converted to FAME through esterification (Lotero et al., 2005) and transesterification reaction as it contains $96.43 \% \mathrm{w}$ triglyceride, which is a potential raw material for fatty acid methyl ester (FAME) or biodiesel production (Juan et al., 2011; Yusup et al., 2015). Biodiesel has numerous advantages such as low carbon content, biodegradable, more efficient combustion and non-toxic than other fuels (Tan et al., 2015). Biodiesel is environmentally friendly due to the easily reabsorbed combustion gases by plants for photosynthesis. Furthermore, it will reduce exhaust emissions without compromising the performance and efficiency of the engine. Use of $100 \%$ biodiesel will reduce $\mathrm{CO}_{2}$ and $\mathrm{SO}_{2}$ emissions by $100 \%$ as well as $\mathrm{CO}$ and $\mathrm{HC}$ emissions by $10-50 \%$ (Havendri, 2008).

Iron sand has the potential to be developed as a catalyst due to hematite $\left(\alpha-\mathrm{Fe}_{2} \mathrm{O}_{3}\right)$ magnetic mineral content. Several studies on biodiesel synthesis using $\mathrm{TiO}_{2}$ supported hematite catalysts from waste cooking oil have been carried out by Zhai et al. (2010), Anuradha et al. (2014) and $\mathrm{CaO}$ supported by Ezzah-Mahmudah et al. (2016) which shown successful biodiesel production with a yield of $92.1 \%, 92.2 \%$ and $92 \%$ respectively. However, the use of $\mathrm{TiO}_{2}$ as catalyst support has significant drawbacks such as small specific surface areas, high cost and potential leaching (Bagheri et al., 2014). Therefore, the need of other catalyst support is crucial. $\mathrm{Al}_{2} \mathrm{O}_{3}$ and ZSM-5 are potential solutions because of large surface areas, lower cost, easily accessible and no potential leaching hazard. Furthermore, $\mathrm{Al}_{2} \mathrm{O}_{3}$ and ZSM-5 were widely used as catalysts in biodiesel production, shown by researches namely Marinkovic et al. (2017), Mohadesi et al. (2015), Zabeti et al. (2009), Fawaz et al. (2019), Estephane et al. (2016) and many more. In this research, waste cooking oil is reacted with 
methanol using $\alpha-\mathrm{Fe}_{2} \mathrm{O}_{3}, \alpha-\mathrm{Fe}_{2} \mathrm{O}_{3} / Z \mathrm{ZSM}-5$ and $\alpha-\mathrm{Fe}_{2} \mathrm{O}_{3} /$ $\mathrm{Al}_{2} \mathrm{O}_{3}$ catalysts to produce biodiesel.

\section{Materials and methods}

\subsection{Materials}

Waste cooking oil was obtained from several nearby restaurants in Tembalang, Semarang. Chemical reagents used are $\mathrm{KOH}$ (85\%, Merck, Germany), $\mathrm{H}_{2} \mathrm{SO}_{4}(95 \%$, Merck, Germany), methanol (99.9\%, Merck, Germany) and distilled water. ZSM-5 (99\%) was purchased online from Alibaba.com and $\mathrm{Al}_{2} \mathrm{O}_{3}(99.9 \%)$ purchased from PT INALUM Indonesia. Iron sand as $\alpha-\mathrm{Fe}_{2} \mathrm{O}_{3}$ resources obtained from Cilacap District Central Java Indonesia.

\subsection{Preparation of catalyst}

Iron sand was separated by magnetic separation method to obtain higher iron content. Hematite $(\alpha-$ $\mathrm{Fe}_{2} \mathrm{O}_{3}$ ) initially undergone chemical precipitation and followed by calcination to obtain the hematite phase $(\alpha$ $\mathrm{Fe}_{2} \mathrm{O}_{3}$ ). A total of $20 \mathrm{~g}$ of iron sand filled in beaker glass is added with $40 \mathrm{~mL}$ of $\mathrm{HCl} 37 \%$. The mixture was stirred at $70^{\circ} \mathrm{C}$ for 30 mins and followed by filtration using Whatman filter paper (No. 1). The filtrate was then mixed with PEG (polyethylene glycol) 4000 which previously has been melted with a volume ratio of 1:5. Then, it was stirred again at $70^{\circ} \mathrm{C}$ for 40 mins until precipitation is formed. The precipitate was washed with distilled water while the catalyst was separated by filtration in vacuum condition. The catalyst then was dried in the oven at $120^{\circ} \mathrm{C}$ for $2 \mathrm{hrs}$ and calcined in the tube furnace at $750^{\circ} \mathrm{C}$. The results of catalyst preparation were presented in Widayat et al. (2019).

\subsection{Waste cooking oil pretreatment}

WCO was pretreated using esterification reaction. WCO was heated to $70^{\circ} \mathrm{C}$ and added with sulfuric acid in methanol. This is considered as the starting point of the reaction. Esterification performed by using methanol is carried out with the following conditions: methanol: waste cooking oil molar ratio of $5: 1$ and $\mathrm{H}_{2} \mathrm{SO}_{4} 1 \%$ w of WCO at $70^{\circ} \mathrm{C}$ for 300 mins. After esterification is carried out, the mixture is moved to separating funnel and washed with warm water. Bottom product and water are discarded while excess methanol is separated from esterification product.

\subsection{Transesterification}

Transesterification method refers to EzzahMahmudah et al. (2016) with slight modifications. Transesterification of waste cooking oil was done by conventional methanol reflux process. A mixture of waste cooking oil, methanol (molar ratio of 15:1) and catalyst $\left(1 \%\right.$ wt of oil) was heated at $65^{\circ} \mathrm{C}$ for $3 \mathrm{hrs}$. The mixture was discharged and centrifuged at $3500 \mathrm{rpm}$ to separate the solid catalyst. After catalyst is separated, liquid product is moved to separating funnel and let to settle to 3 layers for $12 \mathrm{hrs}$. Glycerol at the bottom layer, FAME at the middle and excess methanol at the top. FAME was washed with warm water and done until it is clear which indicates there were no methanol or impurities left in FAME. Water that still contains FAME was removed by evaporation process and the remaining product (FAME) was collected for yield determination and characterization.

\subsection{FAME characterization}

The product was analyzed using GC-MS (Gas Chromatography Mass Spectroscopy). The yield is the ratio of the product obtained to the raw material, or as written on Equation 1:

$\%$ Yield $=\frac{\text { Weight of Biodiesel }(\text { gram })}{\text { Weight of transesterification feed }(\text { gram })} \times 100 \%$

FAME was also analyzed for its density, viscosity and acid number.

\section{Results and discussion}

\subsection{Production and characterization of biodiesel}

In the production of biodiesel, waste cooking oil is used as raw material. Prior to production, waste cooking oil was pretreated to reduce impurity through heating and filtering. The pretreated waste cooking oil can be seen in Figure 1(a) Waste Cooking. The waste cooking oil is then analyzed using GC-MS to determine its content. In addition to GC-MS analysis, \%FFA (free fatty acid) analysis was carried out. From the analysis, it was found that $\%$ FFA contained in waste cooking oil was $6.175 \%$. According to Canakci and Van Gerpen (1999) and Ramadhas et al. (2005) oils with high FFA ( $>2 \%)$ cannot be processed directly with transesterification as it can cause saponification. Saponification reaction occurs between free fatty acids and basic catalysts. Saponification will decrease the effectiveness of the catalyst, which will consequently reduce FAME yield and complicate the separation between FAME and glycerol. Waste cooking oil used in this study has a FFA content above $2 \%(6.178 \%)$. Therefore, the esterification process needs to be carried out to reduce the FFA content. Through esterification, FFA content was successfully reduced to $1.238 \%$ which is in accordance with the requirement of the transesterification process. The results of the transesterification process (biodiesel) can be seen in Figure 1(b) Transesterification results (biodiesel). 
(a)

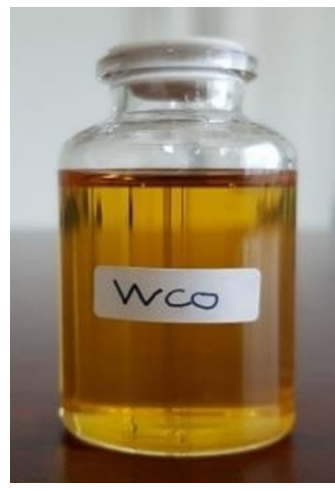

(b)

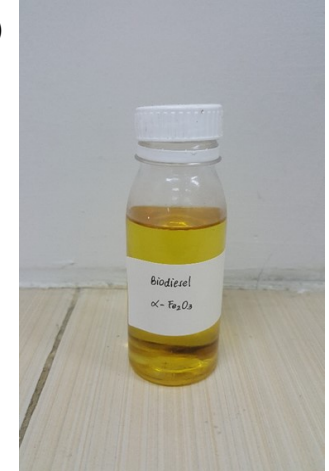

Figure 1. (a) Waste cooking oil (b) Transesterification results (biodiesel)

\subsection{Catalyst pore characterization}

Figure 2(a) and 2(b) shows the surface area and pore volume of $\alpha-\mathrm{Fe}_{2} \mathrm{O}_{3}-\mathrm{ZSM}-5 / \mathrm{Al}_{2} \mathrm{O}_{3}$ respectively. The surface area of the catalysts increases after impregnated with ZSM-5 and $\mathrm{Al}_{2} \mathrm{O}_{3}$. This enlargement is due to the large surface area of the supporting catalyst, $447 \mathrm{~m}^{2} / \mathrm{g}$ for ZSM-5 (Suzuki et al., 1983) and $129 \mathrm{~m}^{2} / \mathrm{g}$ for $\mathrm{Al}_{2} \mathrm{O}_{3}$ (Huang and Stumm, 1972). Impregnation of $\alpha-\mathrm{Fe}_{2} \mathrm{O}_{3}$ to support catalyst will cause pore volume to enlarge. Therefore, a larger surface area of supporting catalyst will result in larger pore volume. However, the pore volume of $\alpha-\mathrm{Fe}_{2} \mathrm{O}_{3} / \mathrm{ZSM}-5$ catalyst is much higher compared to $\alpha-\mathrm{Fe}_{2} \mathrm{O}_{3} / \mathrm{Al}_{2} \mathrm{O}_{3}$ who has a smaller surface area. This is due to the overload of $\alpha-\mathrm{Fe}_{2} \mathrm{O}_{3}$ used $(50 \%$ $\mathrm{w})$, where it would fully fill the pore carrier - leading to blockage - and eventually shrink the surface area.

\subsection{Yield, Fatty Acid Methyl Ester (FAME) and monoglyceride content of biodiesel}

Figure 3 shows the yield and FAME content of the biodiesel produced. It could be seen that yield and FAME obtained was directly proportional to the results of the pore volume obtained in BET analysis. Pore volume represents the active surface in which contacts between the reactants in the reaction process occurs. The greater the active surface of the catalyst, the better the catalyst activity is expected (Ozkar, 2009). Based on the difference in the catalyst, the highest yield and FAME content was produced using $\alpha-\mathrm{Fe}_{2} \mathrm{O}_{3} / Z \mathrm{ZSM}-5$. This is in

(a)

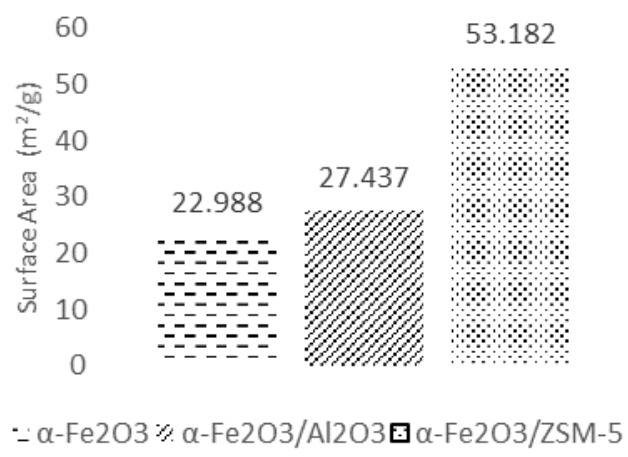

accordance with the earlier statement as ZSM-5 has the largest surface area $447 \mathrm{~m}^{2} / \mathrm{g}$ (Suzuki et al., 1983) among the three catalysts.

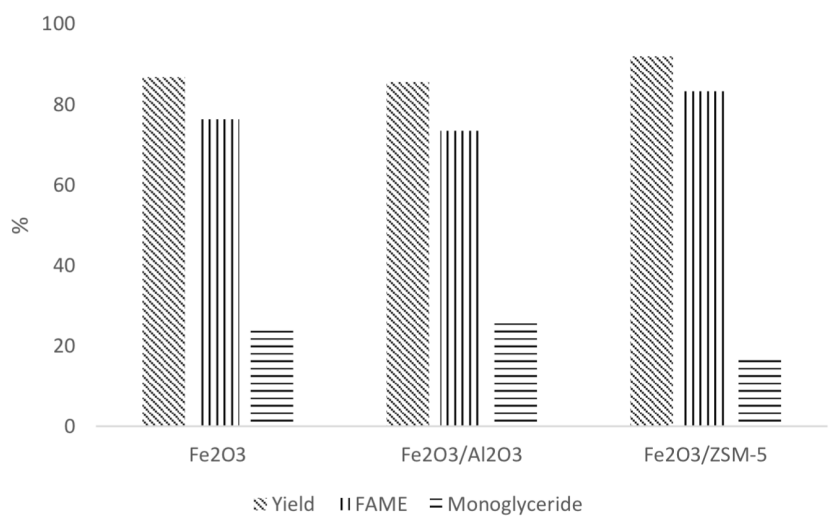

Figure 3. Yield, FAME and monoglyceride content of biodiesel

In addition, it can be concluded that $\alpha-\mathrm{Fe}_{2} \mathrm{O}_{3}$ has a fairly good catalytic ability in biodiesel production. This conclusion was taken because $\alpha-\mathrm{Fe}_{2} \mathrm{O}_{3}$ has twice the pore volume of $\alpha-\mathrm{Fe}_{2} \mathrm{O}_{3} / Z \mathrm{ZSM}-5$. Although the former has higher pore volume, FAME produced was in reality not too far apart. This is probably caused by $\alpha-\mathrm{Fe}_{2} \mathrm{O}_{3}$ which belongs to the class of metal oxides. Metal oxides in heterogeneous catalysts consist of positively charged metal ions which act as electron acceptors, while negative oxygen ions act as proton acceptors. The presence of these active sites causes the catalyst to provide an adsorptive site for methanol where the $\mathrm{O}-\mathrm{H}$ bond will be easily broken into methoxide ions and hydrogen cations. Methoxide anion in the catalyst will react with triglyceride molecules (Refaat, 2011). The formation of this nanocomposite (metal oxide) catalyst will increase catalytic activity due to increased catalyst active site.

\subsection{Density, acid number and viscosity of biodiesel}

Based on Table 1, the density, acid number and viscosity of biodiesel obtained have different values for each variable. It can be concluded that density, acid number and viscosity obtained in this study has good

(b)

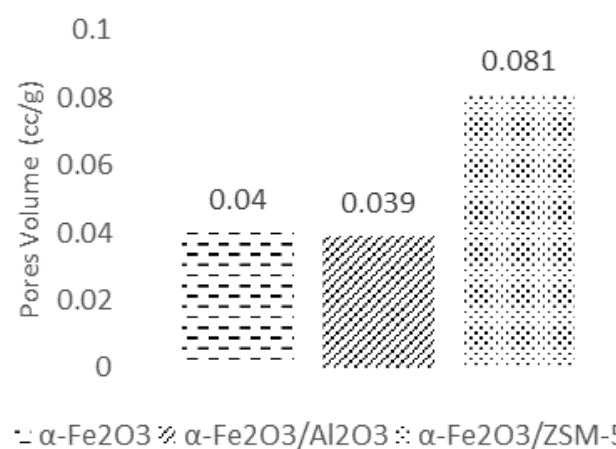

Figure 2. (a) Surface area (b) Pore volume of $\alpha-\mathrm{Fe}_{2} \mathrm{O}_{3}-\mathrm{ZSM}-5 / \mathrm{Al}_{2} \mathrm{O}_{3}$ 
quality because it meets the SNI 7182-2015 biodiesel standard (SNI, 2015).

Table 1. Density, acid number and viscosity of FAME

\begin{tabular}{lcccc}
\hline \multirow{2}{*}{ Parameters } & \multicolumn{3}{c}{ Variable } & SNI \\
\cline { 2 - 4 } & $\alpha-\mathrm{Fe}_{2} \mathrm{O}_{3}$ & $\begin{array}{c}\alpha-\mathrm{Fe}_{2} \mathrm{O}_{3} / \\
\mathrm{ZSM}-5\end{array}$ & $\begin{array}{c}\alpha-\mathrm{Fe}_{2} \mathrm{O}_{3} / \\
\mathrm{Al}_{2} \mathrm{O}_{3}\end{array}$ & \\
\hline $\begin{array}{l}\text { Density } \\
\left(\mathrm{kg} / \mathrm{m}^{3}\right)\end{array}$ & 888.3 & 884.6 & 888.9 & $850-890$ \\
$\begin{array}{l}\text { Acid Number } \\
(\mathrm{mg}-\mathrm{KOH} / \mathrm{g})\end{array}$ & 0.27 & 0.362 & 0.27 & $\operatorname{Max} 0.5$ \\
$\begin{array}{l}\mathrm{Viscosity} \\
\left(\mathrm{mm}^{2} / \mathrm{s}\right)\end{array}$ & 5.685 & 5.312 & 5.889 & $\operatorname{Max} 6$ \\
\hline
\end{tabular}

It cannot be concluded how catalyst influences the differences in biodiesel density, but biodiesel obtained in this study can be said to have good quality because it meets the SNI 7182-2015 biodiesel standard (SNI, 2015). Density is mass per unit volume. Consequently, higher density means it contains more mass which would produce higher emission after combustion (Tuccar et al., 2018). Therefore, the density of the biodiesel produced has to meet the standard quality that is regulated by the government to control the emission.

Furthermore, it also cannot be concluded how catalyst influences the differences in biodiesel acid number. However, it was indicated that the alkalinity of the catalyst affects the value of the acid number. Acid number is used to determine the presence of acid in a sample of biodiesel. In this study, the acid number is obtained from the amount of \%FFA in WCO after the esterification process. The small values of acid number obtained were the result of the effectiveness of catalyst in reducing the acid content during the esterification process. When compared to the SNI acid number standard, biodiesel produced in this study has met the requirement. This is an advantageous property as the high acid number will lead to corrosion in the system (Patel and Shah, 2015).

Viscosity is an important property of fuel which affects the formation of $\mathrm{NO}_{\mathrm{X}}$. Low viscosity will yield lower $\mathrm{NO}_{\mathrm{x}}$ emission, which will lead to a decrease in the greenhouse effect (Tuccar et al., 2018). Based on the SNI viscosity standard for biodiesel, it can be said that biodiesel produced in this study has relatively good quality as it has lower viscosity which would contribute to lower exhaust emission.

\subsection{GC-MS Results}

Results of the GC-MS analysis on biodiesel produced were shown in Figures 4, 5 and 6. Figure 4

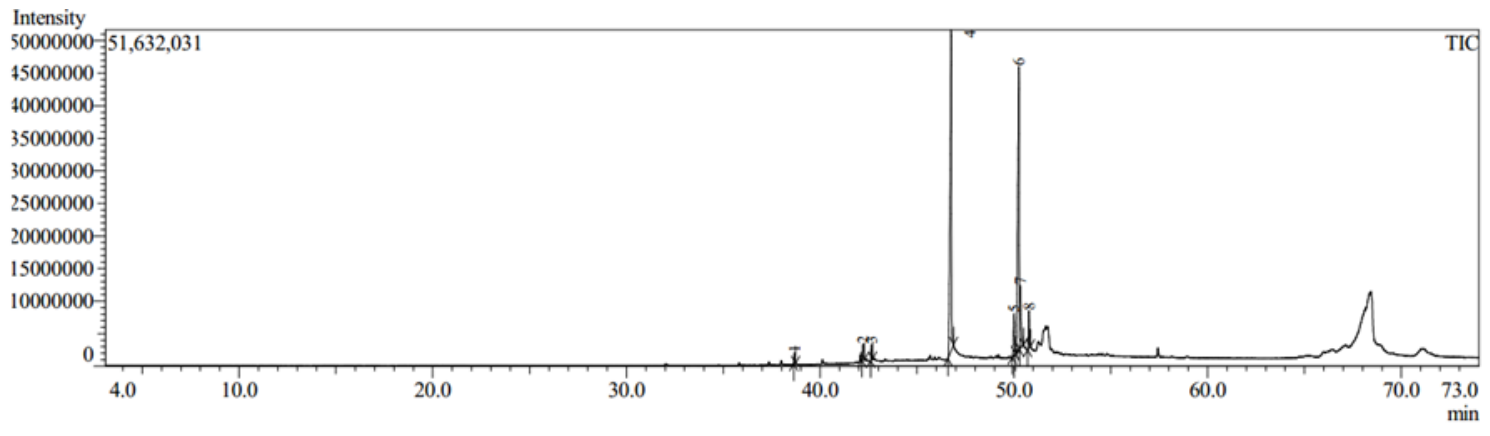

Figure 4. GC-MS result of biodiesel synthesis using $\alpha-\mathrm{Fe}_{2} \mathrm{O}_{3}$ catalyst

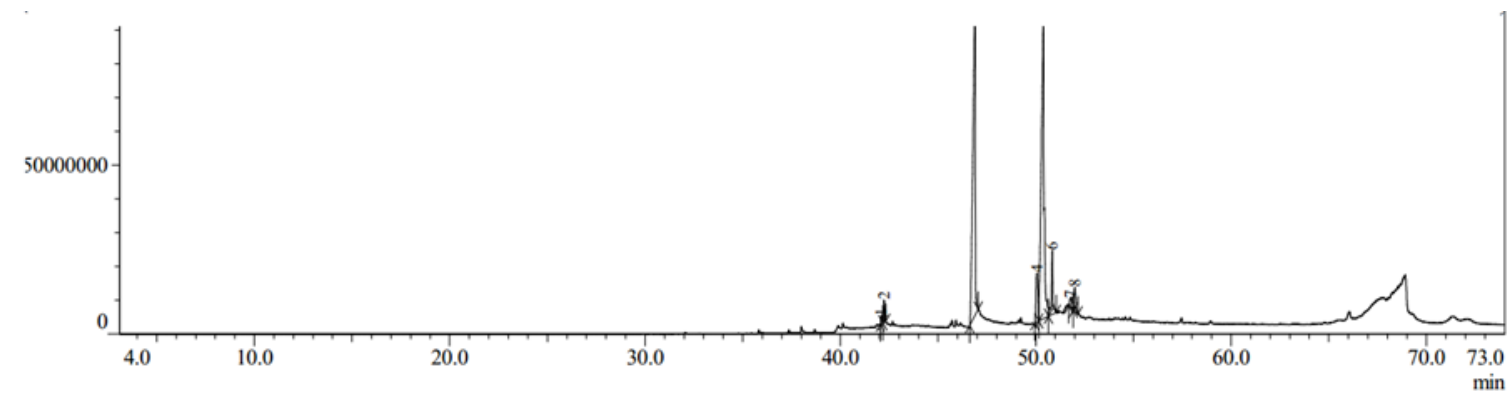

Figure 5. GC-MS result of biodiesel synthesis using $\alpha-\mathrm{Fe}_{2} \mathrm{O}_{3} / \mathrm{Al}_{2} \mathrm{O}_{3}$ catalyst

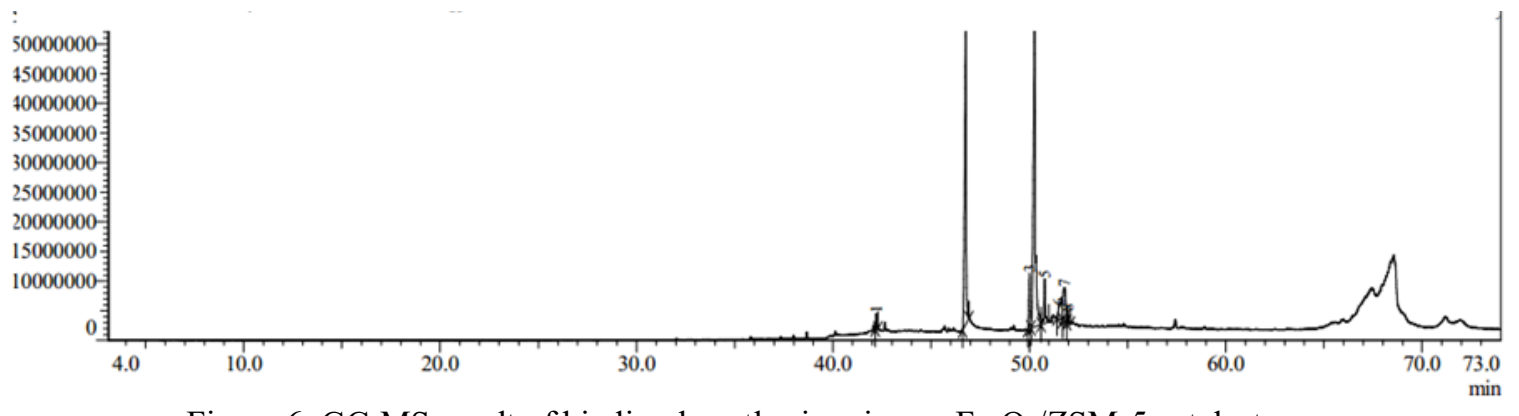

Figure 6. GC-MS result of biodiesel synthesis using $\alpha-\mathrm{Fe}_{2} \mathrm{O}_{3} / \mathrm{ZSM}-5$ catalyst 
shows the result of biodiesel produced using $\alpha-\mathrm{Fe}_{2} \mathrm{O}_{3}$ catalyst. The highest area percentage of $42.63 \%$ is Hexadecanoic acid, 2-hydroxy-1,3-propanediyl ester, a monoglyceride component. The retention time is found to be 46.760 mins. It is followed by glycerol (di-(9octadecenoyl)-glycerol) which has an area percentage of $38.76 \%$, with retention time $50.257 \mathrm{~min}$.

Figure 5 shows the chromatograph result of biodiesel produced using $\alpha-\mathrm{Fe}_{2} \mathrm{O}_{3} / \mathrm{Al}_{2} \mathrm{O}_{3}$ catalyst. The highest percentage of component is found to be glycerol (di-(9octadecenoyl)-glycerol) with an area percentage of $44.43 \%$, retention time of 50.389 mins. Hexadecanoic acid, 2-hydroxy-1,3-propanediyl ester (monoglyceride component) is the second highest component found, with area percentage of $40.18 \%$, retention time of $46.893 \mathrm{~min}$.

Figure 6 shows the result of biodiesel production using $\alpha-\mathrm{Fe}_{2} \mathrm{O}_{3} / \mathrm{ZSM}-5$ catalyst. The highest percentage is found to be the same component as in biodiesel production using $\alpha-\mathrm{Fe}_{2} \mathrm{O}_{3} / \mathrm{Al}_{2} \mathrm{O}_{3}$ catalyst. With area percentage of $42.29 \%$, retention time of $50.270 \mathrm{mins}$, di(9-octadecenoyl)-glycerol is the highest component contained. Followed by Hexadecanoic acid, 2-hydroxy1,3-propanediyl ester (monoglyceride component) with area percentage of $35.36 \%$, retention time of 46.768 mins.

Based on the results, it could be concluded that the $\alpha$ $-\mathrm{Fe}_{2} \mathrm{O}_{3}-\mathrm{ZSM}-5 / \mathrm{Al}_{2} \mathrm{O}_{3}$ catalysts are not selective in producing methyl esters. This could be seen from the formation of monoglyceride component instead of methyl esters. Monoglyceride is the result of direct esterification and/or transesterification of glycerol with fatty acid molecule (Bart et al., 2010). In this study, the production of biodiesel uses simultaneous esterification and transesterification process. Methyl esters which were converted from free fatty acids in WCO during the esterification process will further react with the glycerol present from transesterification, thus forming monoglyceride. The mechanism of monoglyceride

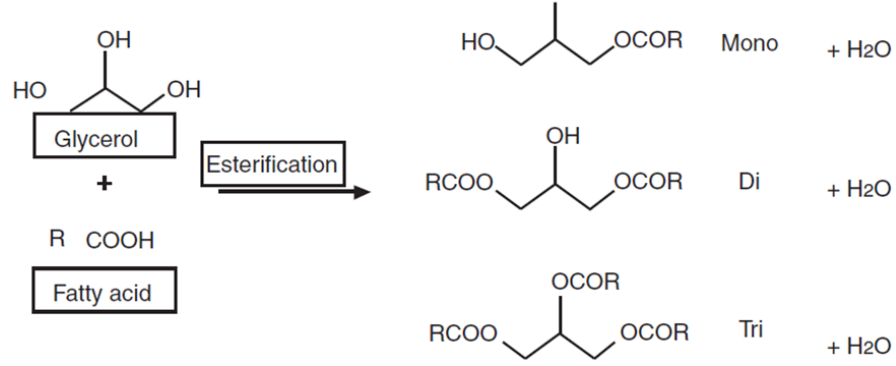

Figure 7. Glycerolysis reaction mechanism (Felizardo et al., 2011)

formation or known as glycerolysis is shown in Figure 7.

\section{Conclusion}

Waste cooking oil can be converted into free fatty acid methyl ester (FAME), glycerol and monoglyceride such as Hexadecanoic acid, 2-hydroxy-1,3-propanediyl ester. Highest biodiesel yield was obtained with the use of $\alpha-\mathrm{Fe}_{2} \mathrm{O}_{3}$-ZSM-5 catalyst (83.28\%). Density, acid number and viscosity of product obtained in this study is in accordance with SNI 7182-2015 biodiesel standards. $\alpha$ $-\mathrm{Fe}_{2} \mathrm{O}_{3}-\mathrm{ZSM}-5 / \mathrm{Al}_{2} \mathrm{O}_{3}$ catalysts were not selective in biodiesel production, proven with the formation of monoglyceride.

\section{Conflict of Interest}

The authors declare no conflict of interest.

\section{Acknowledgments}

This research work was funded by the Ministry of Research Technology and Higher Education, Penelitian Dasar Unggulan Perguran Tinggi (PDUPT) Grant (No. 257-70/UN7.P4.3/PP/2019).

\section{References}

Anuradha, S., Raj, K.J.A., Vijayaraghavan, V.R. and Viswanathan, B. (2014). Sulphated $\mathrm{Fe}_{2} \mathrm{O}_{3}-\mathrm{TiO}_{2}$ Catalysed Transesterification of Soybean Oil to Biodiesel. Indian Journal of Chemistry, 53A, 14931499.

Bagheri, S., Julkapli, N.M. and Hamid, S.B.A. (2014). Titanium Dioxide as a Catalyst Support in Heterogeneous Catalysis. The Scientific World Journal, 2014, $727496 \quad$ http:// dx.doi.org/10.1155/2014/727496.

Bart, J.C.J., Palmeri, N. and Cavallaro, S. (2010). 13 Valorisation of The Glycerol By-product from Biodiesel Production in Biodiesel Science and Technology from Soil to Oil., p. 571-674. Boca Raton: Woodhead Publishing Series in Energy. https://doi.org/10.1533/9781845697761.571

Canakci, M. and Van Gerpen, J.H. (1999). Biodiesel Production via Acid Catalysis. Transactions of the American Society of Agricultural Engineers, 42(5), 1203-1210. https://doi.org/10.13031/2013.13285

Deha, D. (2019). Indonesia's CPO Production Estimating Growth 5\% in 2019. The Insider Stories.

Estephane, J., Saba, T., El Zakhe, H. and Aouad, S. (2016). Biodiesel Production from Sunflower Oil Using ZSM5 Supported Catalysts. Journal of Fundamentals of Renewable Energy and Applications, 6(3 Suppl.), 78.

Ezzah-Mahmudah, S., Lokman, I.M., Saiman, M.I. and Taufiq-Yap, Y.H. (2016). Synthesis and Characterization of $\mathrm{Fe}_{2} \mathrm{O}_{3} / \mathrm{CaO}$ Derived from 
Anadara Granosa for Methyl Ester Production. Energy Conversion and Management, 126, 124-131. https://doi.org/10.1016/j.enconman.2016.07.072

Fawaz, E.G., Salam, D.A., Pinard, L. and Daou, T.J. (2019). Study on the Catalytic Performance of Different Crystal Morphologies of HZSM-5 Zeolites for the Production of Biodiesel: A Strategy to Increase Catalyst Effectiveness. Catalysis Science and Technology, 9(19), 5456-5471. https:// doi.org/10.1039/C9CY01427F

Felizardo, P., Machado, J., Vergueiro, D., Correia, M.J.N., Gomes, J.P. and Bordado, J.M. (2011). Study on The Glycerolysis Reaction of High Free Fatty Acid Oils for Use as Biodiesel Feedstock. Fuel Processing Technology, 92(6), 1225-1229. https:// doi.org/10.1016/j.fuproc.2011.01.020

Havendri, A. (2008). Kaji Eksperimental Prestasi dan Emisi Gas Buang Motor Bahan Bakar Diesel Menggunakan Variasi Campuran Bahan Bakar Biodiesel Minyak Jarak dengan Solar. Jurnal Biodiesel Minyak Jarak, 1, 65-72. [In Bahasa Indonesia].

Huang, C.P. and Werner, S. (1972). The Specific Surface Area of $\gamma-\mathrm{Al}_{2} \mathrm{O}_{3}$. Laboratory of Applied Chemistry. United States of America: Harvard University. https://doi.org/10.1016/0039-6028(72)90160-4

Juan, J.C., Kartika, D.A., Wu, T.Y. and Hin, T.Y.Y. (2011). Biodiesel Production from Jatropha Oil by Catalytic and Non-Catalytic Approaches: An Overview. Bioresource Technology, 102(2), 452460. https://doi.org/10.1016/j.biortech.2010.09.093

Lotero, E., Liu, Y., Lopez, D., Suwannakarn, K., Bruce, D.A. and Goodwin, J.G. (2005). Synthesis of Biodiesel via Acid Catalysis. Industrial and Engineering Chemistry Research, 44, 5353-5363. https://doi.org/10.1021/ie049157g

Marinkovic, D.M., Avramovic, J.M., Stankovic, M.V., Stamenkovic, O.S., Jovanovic, D.M. and Veljkovic, V.B. (2017). Synthesis and Characterization of Spherically-Shaped $\mathrm{CaO} / \gamma-\mathrm{Al}_{2} \mathrm{O}_{3}$ Catalyst and Its Application in Biodiesel Production. Energy Conversion and Management, 144, 399-413. https:// doi.org/10.1016/j.enconman.2017.04.079

Mohadesi, M., Moradi, G. and Rezaei, R. (2015). Biodiesel Production Using $\mathrm{CaO} / \mathrm{Al}_{2} \mathrm{O}_{3}$ Catalyst Synthesized by Sol-Gel Method. The Canadian Journal of Chemical Engineering, 93(9), 1531-1538. https://doi.org/10.1002/cjce.22258

Ozkar, S. (2009). Enhancement of Catalytic Activity by Increasing Surface Area in Heterogeneous Catalyst. Applied Surface Science, 256(5), 1272-1277. https:// doi.org/10.1016/j.apsusc.2009.10.036
Patel, N.K. and Shah, S.N. (2015). 11 - Biodiesel from Plant Oils. In Ahujah, S. (Ed). Food, Energy and Water. The Chemistry Connection., p. 277-307. Oxford: Elsevier. https://doi.org/10.1016/B978-0-12800211-7.00011-9

Ramadhas, A.S., Jayaraj, S. and Muraleedharan, C. (2005). Biodiesel Production from High FFA Rubber Seed Oil. Fuel, 84(4), 335-340. https:// doi.org/10.1016/j.fuel.2004.09.016

Refaat, A.A. (2011). Biodiesel Production Using Solid Metal Oxide. International Journal of Environmental Science and Technology, 8(1), 203221. https://doi.org/10.1007/BF03326210

Standard Nasional Indonesia. (2015). Biodiesel SNI 7182:2015. Retrieved from https://btbrd.bppt.go.id/ index.php/services/26-pojok-biodiesel/94-snibiodiesel

Suzuki, I., Namba, S. and Yashima, T. (1983). Determination of External Surface Area of ZSM-5 Type Zeolite. Journal of Catalysis, 81(2), 485-488. https://doi.org/10.1016/0021-9517(83)90188-4

Tan, Y.H., Abdullah, M.O., Hipolito, C.N. and TaufiqYap, Y.H. (2015). Waste Ostrich- and Chicken Eggshells as Heterogeneous Base Catalyst for Biodiesel Production from Used Cooking Oil: Catalyst Characterization and Biodiesel Yield Performance. Applied Energy, 160, 58-70. https:// doi.org/10.1016/j.apenergy.2015.09.023

Tsai, W.T. (2019). Mandatory Recycling of Waste Cooking Oil from Residential and Commercial Sectors in Taiwan. Resources 8(1), 38. https:// doi.org/10.3390/resources 8010038

Tuccar, G., Tosun, E. and Uludamar, E. (2018). Investigation of Effects of Density and Viscosity of Diesel and Biodiesel Fuels on NOx and Other Emission Formations. Academic Platform Journal of Engineering and Science, 6(2), 81-85. https:// doi.org/10.21541/apjes.371015

Widayat, Suherman and Haryani, K. (2006). Optimasi Proses Adsorbsi Minyak Goreng Bekas dengan Adsorbent Zeolit Alam: Studi Pengurangan Bilangan Asam. Jurnal Teknik Gelagar, 17, 77-82.

Widayat, Putra, D.A. and Nursafitri, I. (2019). Synthesis and Catalytic Evaluation of Hematite $\left(\alpha-\mathrm{Fe}_{2} \mathrm{O}_{3}\right)$ Magnetic Nanoparticles from Iron Sand for Waste Cooking Oil Conversion to Produce Biodiesel Through Esterification-Transesterification Method, presented at IOP Conference Series, Semarang, 2019. Semarang: Materials Science and Engineering. https://doi.org/10.1088/1757-899X/509/1/012035

Yusup, C., Aziz, Bokhari, Klemens and Abdullah, M.Z. (2015). Intensification of Biodiesel Synthesis from 
Waste Cooking Oil (Palm Olein) in A Hydrodynamic Cavitation Reactor: Effect of Operating Parameters on Methyl Ester Conversion. Chemical Engineering and Processing: Process Intensification, 95, 235-240. https://doi.org/10.1016/ j.cep.2015.06.018

Zabeti, M., Daud, W.M.A.W. and Aroua, M.K. (2009). Optimization of The Activity of $\mathrm{CaO} / \mathrm{Al}_{2} \mathrm{O}_{3}$ Catalyst for Biodiesel Production Using Response Surface Methodology. Applied Catalysis A: General, 366(1), 154-159. https://doi.org/10.1016/ j.apcata.2009.06.047

Zhai, D. Nie, Y., Yue, Y., He, H., Hua, W. and Gao, Z. (2010). Esterification and Transesterification on $\mathrm{Fe}_{2} \mathrm{O}_{3}$-doped Sulfated Tin Oxide Catalysts. Catalysis Communications, 12(7), 593-596. https:// doi.org/10.1016/j.catcom.2010.12.020 